\title{
Erysipelothrix rhusiopathiae
}

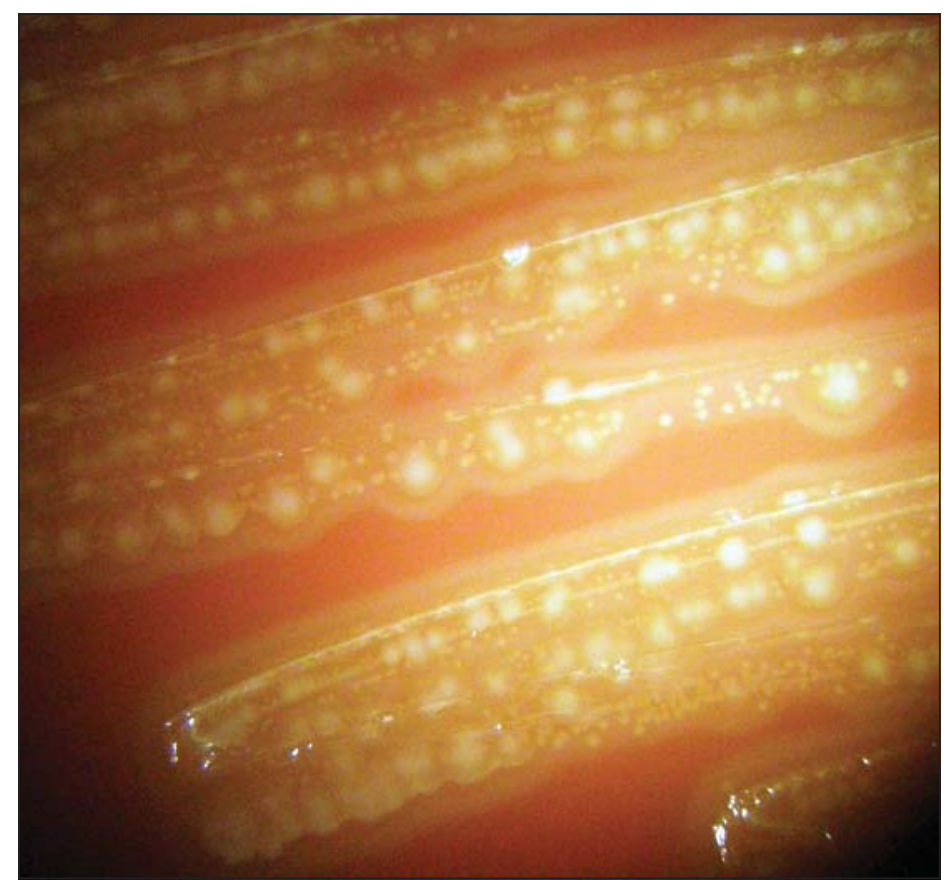

Figura 1. Colonias de Erysipelothrix rhusiopathiae en agar sangre, 48 horas a $37^{\circ} \mathrm{C}$ en $3-5 \% \mathrm{CO}_{2}$. Colonias pequeñas de tipo lisa ( $S$ ) y colonias grande tipo rugosa (R). Lab. MTU 2010.

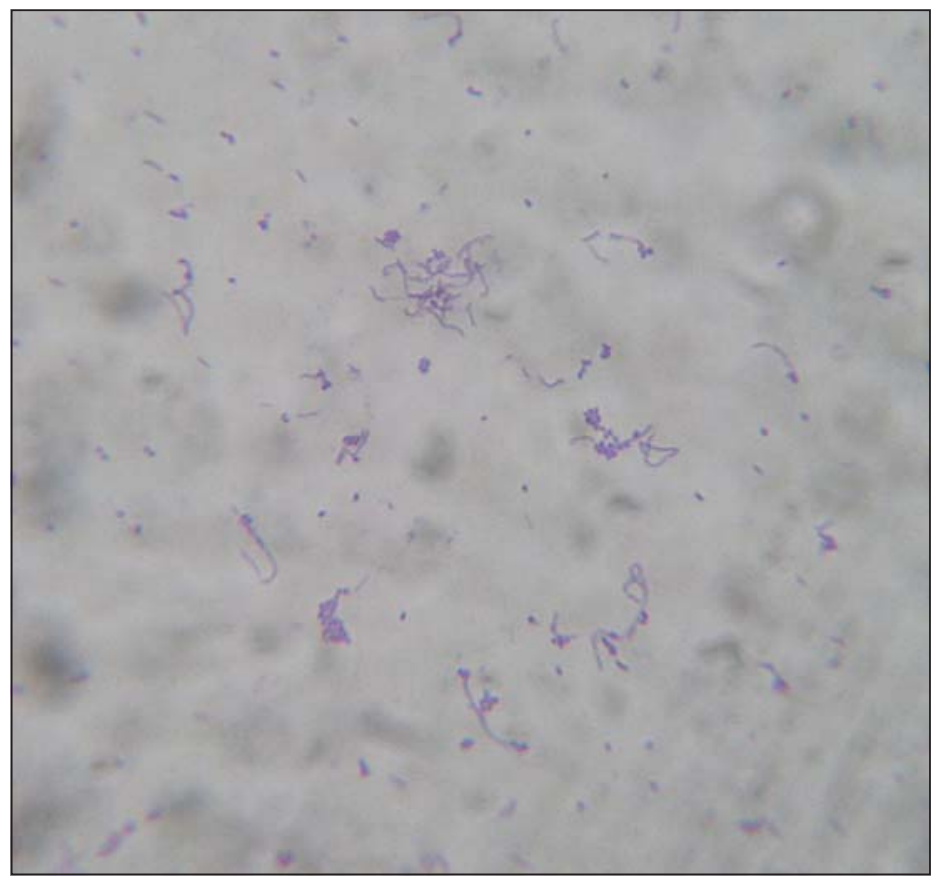

Figura 2. Tinción de Gram de E. rhusiopathiae. Bacilos grampositivo largos y filamentosos, ligeramente curvados con extremos redondeados y bacilos grampositivo pequeños agrupados en pares, cadenas cortas o empalizada tipo difteromorfos. Lab MTU 2010. 


\section{Erysipelothrix rhusiopathiae}

Es un bacilo grampositivo no esporulado ampliamente distribuido en el mundo, comensal o patógeno de animales. La infección en el hombre es rara, generalmente asociada a exposición ocupacional. Puede presentarse, como lesión cutánea localizada, forma cutánea difusa o bacteriemia usualmente asociada con endocarditis. Es anaerobio facultativo; las muestras se incuban en caldo con glucosa $1 \%$, en aerobiosis o $\mathrm{CO}_{2}$ y se subcultiva en agar sangre a las 24 horas. Se puede observar dos tipos de colonias. Una más pequeña y lisa y otra rugosa. La morfología celular está estrechamente ligada al tipo de colonia. Es catalasa, oxidasa, rojo de metilo, indol y Voges Proskauer negativo. Fermenta hidratos de carbono, con producción de ácido, sin gas. La característica más relevante es la producción de $\mathrm{H}_{2} \mathrm{~S}$. Se aísla en hemocultivos tradicionales. Las manifestaciones cutáneas requieren una biopsia de borde de la lesión. Es necesario diferenciar Erysipelothrix, de Listeria spp, Corynebacterium spp y Enterococcus spp.

\section{Referencias}

1.- Brooke C J, and T. V. Riley. 1999. Erysipelothrix rhusiopathiae: bacteriology, epidemiology and clinical manifestations of an occupational pathogen. J Med Microbiol 48: 789-99.

M. Teresa Ulloa F. Microbiología - Micología Facultad de Medicina, Universidad de Chile mtulloa@med.uchile.cl

Una versión in extenso de este Retrato Microbiológico puede encontrarse en www.sochinf.cl 